\title{
A MODEL FOR CONSUMER TRUST IN E-COMMERCE
}

\author{
Mohammad Falahat,* Yan-Yin Lee, Yi-Cheng Foo, and Chee-En Chia \\ Faculty of Accountancy and Management, Universiti Tunku Abdul Rahman, \\ 43000 Kajang, Selangor, Malaysia \\ *Corresponding author: falahat@utar.edu.my
}

Published online: 25 October 2019

To cite this article: Falahat, M., Lee, Y-Y., Foo, Y-C., and Chia, C-E. (2019). A model for consumer trust in e-commerce. Asian Academy of Management Journal, 24(Supp. 2), 93-109. https://doi.org/10.21315/aamj2019.24.s2.7

To link to this article: https://doi.org/10.21315/aamj2019.24.s2.7

\begin{abstract}
E-commerce has grown rapidly over the past decade and has become a significant trend. One of the major concerns for the successful proliferation of e-commerce is the issue of consumers' trust in Internet vendors. This study examines the antecedents of trust in e-commerce among Malaysian online consumers. Data was collected from 300 respondents who had recently made online purchases. Structural equation modelling-partial least squares (SEM-PLS) was used to analyse the data, and our findings reveal that brand recognition, service quality, security, and word-of-mouth (WOM) lead to higher levels of consumer trust, whereas customer satisfaction has an insignificant relation to consumer trust. This study enables online vendors or e-commerce business owners to understand consumer demand and satisfy their needs. Strategies need to be set right too to attract more consumers in purchasing online.
\end{abstract}

Keywords: e-commerce, word of mouth, purchase intention, trust, loyalty

\section{INTRODUCTION}

Electronic commerce (e-commerce) has been growing rapidly, and has become a practical reality for thousands of businesses throughout the world. Companies can now quickly exchange information through the internet, and this has, in turn, brought great benefits to consumers and businesses alike (Liew \& Falahat, 2019). Major corporations like the Federal Administration and the Better Business Bureau have identified that one of the major factors that has been influencing the successful

(C) Asian Academy of Management and Penerbit Universiti Sains Malaysia, 2019. This work is licensed under the terms of the Creative Commons Attribution (CC BY) (http://creativecommons. org/licenses/by/4.0/). 
proliferation of e-commerce is the trust of people in Internet vendors. The primary concern of people that do not engage in online transactions, as claimed by the Better Business Bureau, is online payment security, the reliability of the companies, and the lack of privacy and policy. Trust plays a significant role in innumerable social and economic interactions involving unreliability and dependency. Since unpredictability appears in transactions over the internet, many researchers have found and stated that trust is a critical factor influencing the successful proliferation of e-commerce (Teo \& Liu, 2007). At present, there is a dearth of studies exploring the antecedents of consumer trust. Thus, in order to address this lack, this paper discusses the antecedents of trust among e-commerce consumers. We review prior studies on the antecedents of trust and purchasing intention. Grounded on the Theory of Planned Behaviour (Ajzen, 1991), we identify the variables that could affect trust. Based on the literature on consumer trust and purchasing intention in e-commerce, five variables, namely brand recognition, service quality, customer satisfaction, security, and word-of-mouth communication have an effect on consumer trust, yet the relationships are vague. To the best of our knowledge, these variables have not been empirically tested concurrently in a consumer trust model in the Malaysian context (Oliveira et al., 2017).

\section{LITERATURE REVIEW}

\section{Consumer Trust}

Consumer trust is an important construct that has been frequently studied in e-commerce literature. Trust is a mental shortcut that consumers can use when trying to reduce the uncertainty and complexity of transactions and relationships in electronic markets. An often mentioned reason for consumers not purchasing from Internet vendors is a lack of trust (Petrovic et al., 2003). E-commerce as a novel form of commercial activity implicates more uncertainty and risk than traditional shopping (Lee \& Turban, 2001). Consumer trust is more critical in e-commerce because the consumer cannot touch, feel, and smell the real product. That trust plays a vital role in the relationships between consumers and e-vendors (Fung \& Lee, 1999). Consequences of consumer trust influence consumers' intention to use, or continue to purchase in the e-commerce website (Pavlou, 2003).

Gefen (2000) investigated the role of trust in purchasing behaviour and tested familiarity and disposition to trust as two antecedents for trust in his model. In addition to the consumer characteristics such as propensity to trust, Teo and Liu (2007) explored the attributes of e-commerce vendors. They found that e-commerce vendors' reputation and system assurance affect e-commerce consumer trust. 
The trust encourages the attitude and reduces the perceived risk, thus becomes favourable to purchase intention. Lu, Zhao and Wang (2010) also applied similar variables, e.g., familiarity, perceived similarity, structural assurance, and trust propensity as the antecedents of trust among members in virtual communities and customer-to-customer (C2C) e-commerce. In line with this effort, Fang et al. (2014) reported that satisfaction with a vendor, website quality, and reputation are three significant antecedents of trust in a vendor for repurchase intention. However, they found insignificant paths for familiarity and satisfaction with the Internet.

On the other hand, Palvia (2009) investigated the effects of belief in competence, integrity and benevolence of web vendors on their trustworthiness. In general, the antecedents of trust can be categorised into four types, namely cognition-based factors, affect-based factors, experience-oriented factors, and personality-oriented factors (Kim, Ferrin \& Rao, 2008). Based on this grouping, cognition-based factors refer to perception to security, information quality, etc., affect-based factors which are related to reputation or third-party seal, experience-oriented factor comprises familiarity, and personality-oriented factor refers to a disposition to trust.

Extant literature strongly supports the positive association between consumer trust and intention to purchase in e-commerce. Although consumer trust is critical for e-commerce success, there is a limited exploration of the antecedents of consumer trust (Kim et al., 2008; Teo and Liu, 2007; Oliveira et al., 2017). We fill this literature gap by extending the list of antecedents and empirically test five essential factors which could impact consumer trust in e-commerce. Although it is likely to influence consumer trust, these factors have not been examined empirically in a consumer trust model in the Malaysian context.

\section{Brand Recognition}

Brand recognition mainly depends on consumers' direct experience with a brand and external information of a brand from others (Yoo \& Kim, 2014). Most of the online customers believe that brand names found on top of the webpage are the more famous brands in the e-commerce platforms. Customers generally make desision based on a strong link between brand recognition and consumer preferences to purchase a product (Thoma \& Williams, 2013).

\section{Service Quality}

Wang and Zhang (2016) identified that online service quality is a vital factor to lead to customer satisfaction and long-term development of an online service provider. Based on the study of Rao and Rao (2013), service quality provides a 
strategic advantage for companies as competitors will find it difficult to imitate their service quality standards.

\section{Customer Satisfaction}

Satisfaction is the feeling of happiness or disappointment that rises after comparing the perceived performance of a product against its expected performance (Purwanto \& Kuswandi, 2017). Based on the study of Koay and Derek (2016), the product or service should link with the buyers' expectation that indicates customer satisfaction.

\section{Security}

Based on the study of Skitsko and Ignatova (2016), information security of the online website is a problem among all the online stores. There are some threats to information security. Security can slow down internet and e-commerce growth when customers have lost their confidence towards the protection of their privacy and the security systems (Ruppel, Underwood-Queen \& Harrington, 2003).

\section{Word-of-Mouth}

Word-of-mouth (WOM) is a crucial source of information created by individuals or marketers, and consumers or marketers disseminate it to other consumers (Hidayanto et al., 2017). Berger and Schwartz (2011) found that unique and interesting products get more immediate WOM but do not receive more sustaining WOM over time.

Consequences of consumer trust influence consumers' intention to use, or continue to purchase in the e-commerce website (Pavlou, 2003). Some consumers are not ready to shop online because they do not trust the businesses in the e-commerce platform.

\section{Hypothesis Development}

\section{The association between brand recognition and consumer trust}

According to the study of Ma and Chan (2014), online users will search for the brands that they recognise or are already famous when they are looking for a product. They are likely to search for ad rankings online. Additionally, it suggests the effects of ad ranking on online users' brand recognition. Usually, a customer will purchase a product by a recognised brand because they trust the brand. 
Therefore, brand recognition significantly affects consumer trust (Oliveira et al., 2017). Yoo and Kim (2014) highlighted that online users search for the brands that they recognise or which are famous when they are looking for a product. Thus, we hypothesise:

H1: Brand recognition positively relates to consumer trust

\section{The association between service quality and consumer trust}

From an e-service viewpoint, consumer trust is the concept that exists when one party has confidence in the other party's service quality (Wang \& Zhang, 2016). The possibility of being able to interact with the seller to obtain more information about the product will influence the user's willingness to perform online transaction (Hoffman, Novak \& Peralta, 1999). Thus, excellent service quality can improve consumer trust (Oliveira et al., 2017). Therefore, we hypothesise:

$\mathrm{H} 2$ : Service quality positively relates to consumer trust

\section{The association between customer satisfaction and consumer trust}

Customer satisfaction is closely related to consumer trust (Delgado-Ballester \& Munuera-Alemán, 2001; Oliveira et al., 2017). In e-commerce, the service provider's inability to meet consumer needs leads to the dissatisfaction of consumers (Dolinsky, 1994; Halstead, Dröge \& Bixby, 1993). Consumer's satisfaction refers to satisfaction on the functional performance of the product and its attributes (Ha $\&$ Perks, 2005). The feeling of satisfaction tends to create a perception that the vendor is reliable and responsible for the interests and welfare of the consumer (Delgado-Ballester \& Munuera-Alemán, 2001). Thus, we hypothesise:

H3: Customer satisfaction positively relates to consumer trust

\section{The association between security and consumer trust}

Among the critical dimensions of online shopping, security and privacy issues are the uppermost concern for consumers. The majority of consumers engaging in online purchases are very concerned about the lack of security concerning personal information; of companies using personal information to send unsolicited materials, the dissemination of personal information to third parties, and fraud, especially regarding credit card information (Miyazaki \& Fernandez, 2001). 
An assured online security could also reduce perceptions of risk associated with transactions (Wang \& Zhang, 2016) and positively affect consumer trust (Oliveira et al., 2017). Thus, we hypothesise:

H4: Security positively relates to consumer trust

\section{The association between WOM communication and consumer trust}

Awad and Ragowsky (2008) stated that online WOM systems are focused on information-based communication and sharing of information about products to others. Additionally, the perception of WOM systems quality is based on what benefit the WOM system can provide to customers. Customers will likely perceive the product-specific exchange of information to be beneficial and thus perceive the online retailer as more credible, which is an element of online trust. Therefore, customers expect that WOM quality will have a positive impact on the trustworthiness of the e-commerce platform. Prior literature has shown that offline WOM will reduce risk perception (Garbarino \& Strahilevitz, 2004). Hence, customer feedback on online WOM system will affect consumer trust. Thus, we hypothesise:

H5: WOM communication positively relates to consumer trust

\section{Research Framework}

This study intends to test five hypotheses presented above, and our research framework is shown in Figure 1.

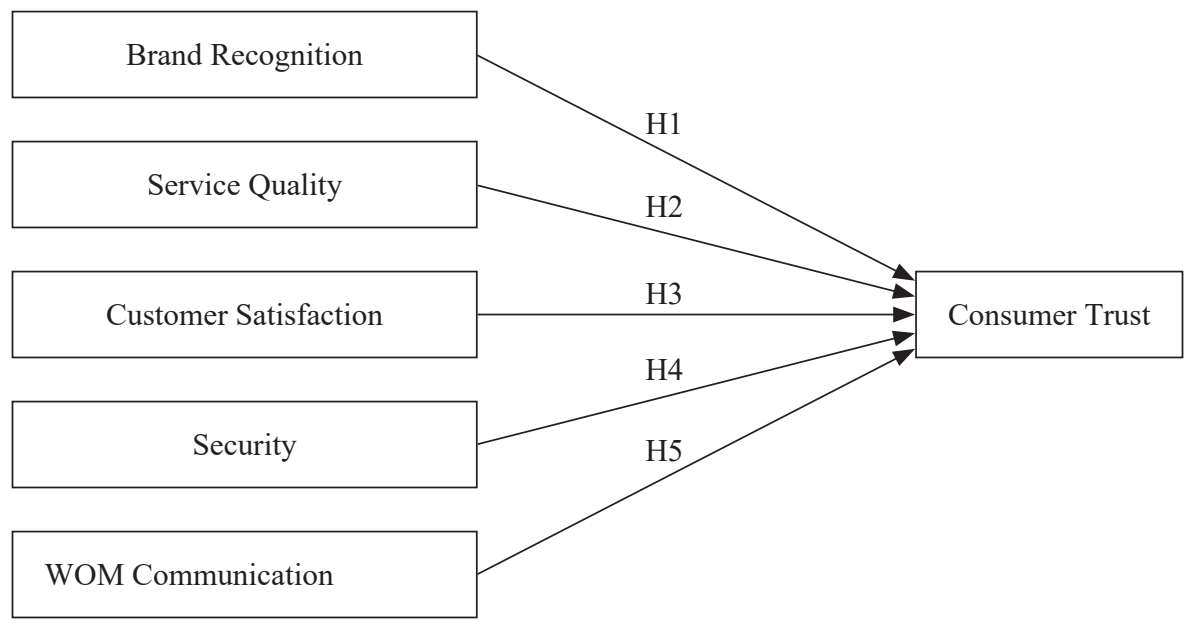

Figure 1. Research framework 


\section{RESEARCH METHODOLOGY}

\section{Data Collection}

We collected the data from random Internet users through an online survey. The questionnaire was distributed through an online Google Forms application with a total of 22 questions. The poll was developed based on a literature review (see Appendix A).

We collected the responses from 300 respondents who had recently made online purchases. They responded to the questions we asked about the online vendors that they had recently purchased from. The collected data were not altered in any way as they were gained first-hand. This reflects the authenticity and reliability of the data as the collected results are of the personal opinions of the respondents. The survey was conducted mainly online and therefore the entire exercise involved minimal expenses. The questionnaire containing 22 questions has provided sufficient and detailed information for the reliability and accuracy of the test.

\section{Respondents' Profile}

The target of this study were individuals of all ages who had recently purchased online. They were asked to answer the questionnaire concerning a specific online vendor that they have purchased from recently. Details of the respondents' profile were summarised in Table 1.

\section{Data Analysis}

Using structural equations modeling via SmartPLS, we performed a two-stage analytical procedure to assess the measurement model for reliability and validity, and structural path modeling for hypothesis testing (Falahat \& Migin, 2017; Falahat et al., 2017). We performed confirmatory factor analysis (CFA) to assess reliability, convergent validity, and discriminant validity. As per suggestion by Hair et al. (2017), convergent validity could be evaluated through loadings, average variance extracted (AVE), and composite reliability (CR). The loadings, Cronbach's alpha, CR, and AVE are presented in Table 2. As shown in Table 2, all items' loadings are well above the recommended values of 0.708 (Hair et al., 2017). CR for all constructs are well above the cut-off value of 0.5 . It was noted that the AVE for all latent variables are higher than the recommended value of 0.5 which indicates strong reliability of constructs. 
Mohammad Falahat et al.

Table 1

Respondents' profile

\begin{tabular}{|c|c|c|}
\hline Characteristics & Frequency & Percentage $(\%)$ \\
\hline \multicolumn{3}{|l|}{ Online purchase experience } \\
\hline $1-3$ years & 189 & 63 \\
\hline 4-6 years & 93 & 31 \\
\hline Above 6 years & 5 & 2 \\
\hline Unknown & 13 & 4 \\
\hline \multicolumn{3}{|l|}{ Monthly income (RM) } \\
\hline No income & 9 & 3 \\
\hline Student & 4 & 1 \\
\hline Below RM1,500 & 3 & 1 \\
\hline RM1,500-RM3,000 & 85 & 28 \\
\hline RM3,001-RM4,000 & 40 & 13 \\
\hline RM4,001-RM5,500 & 50 & 17 \\
\hline RM5,501-RM8,500 & 44 & 15 \\
\hline RM8,501-RM15,000 & 36 & 12 \\
\hline Unknown & 29 & 10 \\
\hline \multicolumn{3}{|l|}{ Gender } \\
\hline Female & 165 & 55 \\
\hline Male & 135 & 45 \\
\hline \multicolumn{3}{|l|}{ Age } \\
\hline $18-24$ & 104 & 35 \\
\hline $25-29$ & 65 & 22 \\
\hline $30-34$ & 44 & 15 \\
\hline $35-39$ & 37 & 12 \\
\hline $40-44$ & 18 & 6 \\
\hline $45-49$ & 11 & 4 \\
\hline Others & 21 & 7 \\
\hline \multicolumn{3}{|l|}{ Education level } \\
\hline Secondary & 28 & 9 \\
\hline Diploma & 43 & 14 \\
\hline Bachelor's degree & 193 & 64 \\
\hline Postgraduate & 36 & 12 \\
\hline
\end{tabular}


Table 2

Result of construct reliability and validity

\begin{tabular}{|c|c|c|c|c|c|}
\hline & Item & Outer loadings & Cronbach's alpha & $\mathrm{CR}$ & AVE \\
\hline \multirow[t]{5}{*}{ Consumer trust } & $\mathrm{CT} 1$ & 0.818 & 0.887 & 0.917 & 0.690 \\
\hline & $\mathrm{CT} 2$ & 0.815 & & & \\
\hline & CT3 & 0.846 & & & \\
\hline & CT4 & 0.825 & & & \\
\hline & CT5 & 0.846 & & & \\
\hline \multirow[t]{3}{*}{ Brand recognition } & BR1 & 0.836 & 0.760 & 0.862 & 0.675 \\
\hline & BR2 & 0.833 & & & \\
\hline & $\mathrm{BR} 3$ & 0.797 & & & \\
\hline \multirow[t]{3}{*}{ Customer satisfaction } & $\mathrm{CS} 1$ & 0.872 & 0.821 & 0.893 & 0.737 \\
\hline & $\mathrm{CS} 2$ & 0.829 & & & \\
\hline & CS3 & 0.873 & & & \\
\hline \multirow[t]{5}{*}{ Security } & S1 & 0.872 & 0.924 & 0.943 & 0.767 \\
\hline & $\mathrm{S} 2$ & 0.877 & & & \\
\hline & S3 & 0.891 & & & \\
\hline & S4 & 0.891 & & & \\
\hline & S5 & 0.848 & & & \\
\hline \multirow[t]{4}{*}{ Service quality } & SQ1 & 0.777 & 0.833 & 0.889 & 0.666 \\
\hline & SQ2 & 0.814 & & & \\
\hline & SQ3 & 0.848 & & & \\
\hline & SQ4 & 0.826 & & & \\
\hline \multirow[t]{2}{*}{ WOM } & WOM1 & 0.894 & 0.709 & 0.873 & 0.774 \\
\hline & WOM2 & 0.865 & & & \\
\hline
\end{tabular}

Based on Table 2, there are endogenous variables and exogenous variables. These variables consist of brand recognition, customer satisfaction, security, service quality, WOM communication, and consumer trust.

Outer loadings are the relationship for reflective constructs. The size of the outer loading is also commonly called indicator reliability. High outer loadings on a construct indicate the associated indicators have much in common, which is captured by the construct. The standard outer loading should be 0.7 or higher. As a result, the overall outer loadings value is above 0.7 which means that variables in the test achieved the validity and reliability (Hair et al., 2017). Cronbach's alpha is a measure of internal consistency which closely related a set of items are as a group. A reliability coefficient of 0.70 or higher is considered "acceptable" in 
research. As a result, the overall Cronbach's alpha value is above 0.7 which means that variables in the test are highly correlated. The CR value which is also above 0.7 further confirms the reliability of internal consistency. AVE is a measurement of the amount of variance captured by a construct about the amount of variance due to measurement error. A validity coefficient of 0.50 or higher is considered "acceptable" in research. From Table 2, the overall AVE value is above 0.50 which means that variables in the test are highly correlated. As for the R-square $\left(\mathrm{R}^{2}\right)$ value for the consumer trust is 0.700 .

\section{RESULTS}

The results show significant positive association between brand recognition $(\mathrm{H} 1)$, service quality (H2), security (H4), WOM (H5), and consumer trust. Furthermore, our results confirm that there is no significant positive association between customer satisfaction and consumer trust (H3). Table 3 presents the summary results of hypothesis testing.

Table 3

Summary results of hypothesis testing

\begin{tabular}{llccc}
\hline Hypothesis & Description & t value & $p$-value & Result \\
\hline H1 & $\begin{array}{l}\text { Brand recognition positively relates } \\
\text { to consumer trust }\end{array}$ & 5.723 & 0.000 & Supported \\
H2 & $\begin{array}{l}\text { Service quality positively relates } \\
\text { to consumer trust }\end{array}$ & 4.026 & 0.000 & Supported \\
H3 & $\begin{array}{l}\text { Customer satisfaction positively } \\
\text { relates to consumer trust }\end{array}$ & 1.704 & 0.091 & Not supported \\
H4 & $\begin{array}{l}\text { Security positively relates to } \\
\text { consumer trust }\end{array}$ & 4.605 & 0.000 & Supported \\
H5 & $\begin{array}{l}\text { WOM positively relates } \\
\text { to consumer trust }\end{array}$ & 2.299 & 0.022 & Supported \\
\hline
\end{tabular}

\section{DISCUSSION}

This research would be very useful for those thinking of venturing into e-commerce platform and starting a business. It is of great significance to business or enterprise owners in understanding the needs of consumers in this era of online shopping. Through this study, online vendors or e-commerce business owners will be able to gain a deeper understanding of the importance and the impact of antecedents affecting consumer trust in e-commerce. Factors such as brand recognition, service 
quality, customer satisfaction, security, and WOM communication were tested through the survey and the results have been analysed to understand the consumer's main concerns and thoughts. As trust is important among the consumers, it is important to know the perception of the consumers in order to expand the online business. When trust is instilled in consumers, it will lead to loyalty and purchase intention.

The findings will contribute to the literature on the importance of consumer trust in e-commerce. Based on our understanding, prior research has not employed these variables in primary data survey (Kim et al., 2008; Teo \& Liu, 2007). While demonstrating the significant role of brand recognition, service quality, security and WOM communications on consumer trust in e-commerce, the result also highlights that customer satisfaction should not be considered as an antecedent for consumer trust. A possible explanation is that customer satisfaction can only be judged after at least one purchase from the e-commerce vendor, unlike other variables which can be assessed before the purchase. Consumer trust in e-commerce seems to be supported by factors that can be observed prior to their initial purchase experience. This is an interesting topic for a better understanding of consumer trust's antecedents. In future, researchers may consider further to validate the insignificant relationship between customer satisfaction and consumer trust, examine its influence on repurchase intention or identify any possible factors that moderate this relationship, for instance, the service quality or security. According to Fang et al. (2014), customer satisfaction affects the trust related to repurchase behaviour after consumers learn from their past transaction experience. Their findings also show that when the perceived effectiveness of institutional e-commerce mechanism is low, customer satisfaction has an insignificant effect on trust.

For e-commerce vendors who wish to increase consumer trust on their platform, the findings reveal that a few considerations should be taken when developing their e-commerce site. First, e-commerce vendors may assess whether their brand is well recognised. They could also leverage the effects of some popular brands to encourage website traffic to their e-commerce site. Second, e-commerce vendors must ensure prompt response and professional feedback to an enquiry from a potential consumer in view that their service quality will determine the level of consumer trust. Third, e-commerce vendors need to emphasise the security and protection of consumers' information through clear description and presentation of such commitment on their e-commerce site to gain consumers' trust. Lastly, the existence of transparent e-commerce site that supports the online WOM communication provides better confidence to consumers; this will gain more trust. 
The research findings conjecture that consumers have better trust on e-commerce sites that fulfill these criteria, and e-commerce vendors should not ignore these actions if they intend to encourage purchase behaviours.

This study has some limitations. In terms of generalisability, the data was limited to samples from a single country, i.e., Malaysia. A review of this model in a different country context will help to validate the findings. Also, our data is a representation of current e-commerce users' trust antecedents. Future studies may explore the trust antecedents for non-e-commerce users. It is also essential to understand the factors that may negatively influence the trust such as impacts of previous fraud experience on consumer trust.

\section{CONCLUSION}

This study empirically tests five antecedents for consumer trust in e-commerce. The outcomes of this research reveal that brand recognition, service quality, security, and WOM communication positively affect consumer trust in e-commerce. It also contributes to the evidence for a deduction that customer satisfaction does not significantly influence consumer trust. It alerts researchers for considerations of different antecedents for consumer trusts between initial purchase and repurchase in the future research setting. In conclusion, the findings indicate that e-commerce vendors should set their strategies right to enhance consumer trust and attract more consumers for online purchases.

\section{REFERENCES}

Ajzen, I. (1991). The theory of planned behavior. Organizational Behavior and Human Decision Processes, 50(2), 179-211. https://doi.org/10.1016/07495978(91)90020-T

Awad, N.F., \& Ragowsky, A. (2008). Establishing trust in electronic commerce through online word of mouth: An examination across genders. Journal of Management Information Systems, 24(4), 101-121. https://doi.org/10.2753/MIS07421222240404

Berger, J., \& Schwartz, E.M. (2011). What drives immediate and ongoing word of mouth? Journal of Marketing Research, 48(5), 869-880. https://doi.org/10.1509/ jmkr.48.5.869

Delgado-Ballester, E., \& Munuera-Alemán, L.J. (2001). Brand trust in the context of consumer loyalty. European Journal of Marketing, 35(11/12), 1238-1258. https://doi.org/10.1108/EUM0000000006475 
Dolinsky, A.L. (1994). A consumer complaint framework with resulting strategies: An application to higher education. Journal of Services Marketing, 8(3), 27-39. https://doi.org/10.1108/08876049410065598

Falahat, M., Migin, M.W., Chong, S.C., \& Sia, B.K. (2017). Determinants of consumer impulse buying behaviour in context of footwear industry. Advanced Science Letters, 23(4), 3068-3070. https://doi.org/10.1166/asl.2017.7655

Falahat, M., \& Migin, M.W. (2017). Export performance of international new ventures in emerging market. International Journal of Business and Globalisation, 19(1), 111-125. https://doi.org/10.1504/IJBG.2017.085119

Fang, Y., Qureshi, I., Sun, H., McCole, P., Ramsey, E., \& Lim, K.H. (2014). Trust, satisfaction, and online repurchase intention: The moderating role of perceived effectiveness of e-commerce institutional mechanisms. MIS Quarterly, 38(2). https://doi.org/10.25300/MISQ/2014/38.2.04

Fung, R., \& Lee, M. (1999). EC-trust (trust in electronic commerce): Exploring the antecedent factors. AMCIS 1999 Proceedings, 179.

Garbarino, E., \& Strahilevitz, M. (2004). Gender differences in the perceived risk of buying online and the effects of receiving a site recommendation. Journal of Business Research, 57(7), 768-775. https://doi.org/10.1016/S0148-2963(02)00363-6

Gefen, D. (2000). E-commerce: The role of familiarity and trust. Omega The International Journal of Management Science, 28(6), 725-737. https://doi.org/10.1016/S03050483(00)00021-9

Guo, X., Ling, K.C., \& Liu, M. (2012). Evaluating factors influencing consumer satisfaction towards online shopping in China. Asian Social Science, 8(13), 40.

Ha, H.Y., \& Perks, H. (2005). Effects of consumer perceptions of brand experience on the web: Brand familiarity, satisfaction and brand trust. Journal of Consumer Behaviour, 4(6), 438-452. https://doi.org/10.1002/cb.29

Halstead, D., Dröge, C., \& Bixby Cooper, M. (1993). Product warranties and post-purchase service: A model of consumer satisfaction with complaint resolution. Journal of Services Marketing, 7(1), 33-40. https://doi.org/10.1108/08876049310026088

Hidayanto, A.N., Ovirza, M., Anggia, P., Budi, N.F.A., \& Phusavat, K. (2017). The roles of electronic word of mouth and information searching in the promotion of a new E-commerce strategy: A case of online group buying in Indonesia. Journal of Theoretical and Applied Electronic Commerce Research, 12(3), 69-85. https://doi.org/10.4067/S0718-18762017000300006

Hoffman, D.L., Novak, T.P., \& Peralta, M. (1999). Building consumer trust online. Communications of the ACM, 42(4), 80-85. https://doi.org/10.1145/299157. 299175

Hair, J.F., Hult, G.T.M., Ringle, C., \& Sarstedt, M. (2017). A primer on partial least squares structural equation modeling. Thosand Oaks, CA: SAGE. https://doi.org/10.15358/9783800653614

Kim, D.J., Ferrin, D.L., \& Rao, H.R. (2008). A trust-based consumer decision-making model in electronic commerce: The role of trust, perceived risk, and their antecedents. Decision Support Systems, 44(2), 544-564. https://doi.org/10.1016/j. dss.2007.07.001 
Koay, K.Y., \& Derek, O.L.T. (2016). The mediating role of customer satisfaction in Customer Retention Model: A case of local automobile brands in Malaysia. Pertanika Journal Social Sciences \& Humanities, 24(S), 27-40.

Lee, M.K., \& Turban, E. (2001). A trust model for consumer internet shopping. International Journal of Electronic Commerce, 6(1), 75-91. https://doi.org/10.1080/10864415 .2001 .11044227

Liew, Y.S., \& Falahat, M. (2019). Factors influencing consumers' purchase intention towards online group buying in Malaysia. International Journal of Electronic Marketing and Retailing, 10(1), 60-77. https://doi.org/10.1504/IJEMR.2019.096627

Lu, Y., Zhao, L., \& Wang, B. (2010). From virtual community members to C2C e-commerce buyers: Trust in virtual communities and its effect on consumers' purchase intention. Electronic Commerce Research and Applications, 9(4), 346360. https://doi.org/10.1016/j.elerap.2009.07.003

Ma, W.W., \& Chan, A. (2014). Knowledge sharing and social media: Altruism, perceived online attachment motivation, and perceived online relationship commitment. Computers in Human Behavior, 39, 51-58. https://doi.org/10.1016/j. chb.2014.06.015

Miyazaki, A.D., \& Fernandez, A. (2001). Consumer perceptions of privacy and security risks for online shopping. Journal of Consumer Affairs, 35(1), 27-44. https://doi. org/10.1111/j.1745-6606.2001.tb00101.x

Nguyen, N., \& Leblanc, G. (2001). Corporate image and corporate reputation in customers' retention decisions in services. Journal of Retailing and Consumer Services, 8(4), 227-236. https://doi.org/10.1016/S0969-6989(00)00029-1

Oliveira, T., Alhinho, M., Rita, P., \& Dhillon, G. (2017). Modelling and testing consumer trust dimensions in e-commerce. Computers in Human Behavior, 71, 153-164. https://doi.org/10.1016/j.chb.2017.01.050

Palvia, P. (2009). The role of trust in e-commerce relational exchange: A unified model. Information \& Management, 46, 213-220. https://doi.org/10.1016/j. im.2009.02.003

Pavlou, A.P. (2003). Consumer acceptance of electronic commerce: Integrating trust and risk with the Technology Acceptance Model. International Journal of Electronic Commerce, 7(3), 101-134. https://doi.org/10.1080/10864415.2003.11044275

Petrovic, O., Ksela, M., Fallenbock, M., Kittl, C., Urban, G.L., \& Zobel, R. (2003). Trust in the network economy. Santa Clara, CA: Springer-Verlag. https://doi. org/10.1007/978-3-7091-6088-6

Purwanto, P., \& Kuswandi, K. (2017). Effects of flexibility and interactivity on the perceived value of and satisfaction with e-commerce (evidence from Indonesia). Market-Tržište, 29(2), 139-159. https://doi.org/10.22598/mt/2017.29.2.139

Rao, A.S., \& Rao, V.G. (2013). Service quality in e-commerce and strategic advantage: An empirical assessment. IUP Journal of Business Strategy, 10(2), 50-66.

Ruppel, C., Underwood-Queen, L., \& Harrington, S.J. (2003). E-commerce: The roles of trust, security, and type of e-commerce involvement. e-Service Journal, 2(2), 25-45. https://doi.org/10.2979/esj.2003.2.2.25 
Skitsko, V., \& Ignatova, I. (2016). Modeling the process of purchase payment as a constituent of information security in e-commerce. Operations Research and Decisions, 3, 83-99.

Teo, T.S.H., \& Liu, J. (2007). Consumer trust in e-commerce in the United States, Singapore and China. Omega The International Journal of Management Science, 35(1), 22-38. https://doi.org/10.1016/j.omega.2005.02.001

Thoma, V., \& Williams, A. (2013). The devil you know: The effect of brand recognition and product ratings on consumer choice. Judgment \& Decision Making, 8(1), 34- 44.

Wang, C., \& Zhang, M. (2016). Empirical study the influences of customer orientation, service quality on behavioral intention based on China's consumer-to-consumer e-commerce context. Journal of the Balkan Tribological Association, 22(2), 2176-2195.

Yoo, J., \& Kim, M. (2014). The effects of home page design on consumer responses: Moderating role of centrality of visual product aesthetics. Computers in Human Behavior, 38, 240-247. https://doi.org/10.1016/j.chb.2014.05.030 


\section{APPENDIX A - CONSTRUCTS (5-POINT LIKERT SCALE)}

Brand Recognition (source: Nguyen \& Leblanc, 2001)

\begin{tabular}{llcc}
\hline & Questions & Mean & Std. deviation \\
\hline 1 & $\begin{array}{l}\text { In my opinion, my current online vendor has a good image } \\
\text { in the minds of consumers. }\end{array}$ & 4.03 & 0.775 \\
2 & $\begin{array}{l}\text { In general, I believe that my current online vendor always } \\
\text { fulfils the promises that it makes to its customers. }\end{array}$ & 3.99 & 0.793 \\
3 & $\begin{array}{l}\text { I would encourage friends and relatives to do business } \\
\text { with my current online vendor. }\end{array}$ & 3.95 & 0.763 \\
\hline
\end{tabular}

Service Quality (source: Palvia, 2009)

\begin{tabular}{|c|c|c|c|}
\hline & Questions & Mean & Std. deviation \\
\hline 1 & $\begin{array}{l}\text { The time I spend to shop at this vendor's website is highly } \\
\text { reasonable. }\end{array}$ & 3.92 & 0.832 \\
\hline 2 & $\begin{array}{l}\text { The effort involved in shopping at this vendor's website is } \\
\text { worthwhile. }\end{array}$ & 3.94 & 0.784 \\
\hline 3 & The shopping experience at this vendor's website is excellent. & 3.95 & 0.818 \\
\hline 4 & I found significant value by shopping at this vendor's website. & 3.92 & 0.793 \\
\hline
\end{tabular}

Customer Satisfaction (source: Palvia, 2009)

\begin{tabular}{llcc}
\hline \multicolumn{2}{c}{ Questions } & Mean & Std. deviation \\
\hline 1 & $\begin{array}{l}\text { Overall, I am satisfied with the current online vendor that } \\
\text { I have in mind. }\end{array}$ & 0.720 \\
$2 \quad \begin{array}{l}\text { I am very pleased with making purchases from my current } \\
\text { online vendor. }\end{array}$ & 4.03 & 0.740 \\
$3 \quad \begin{array}{l}\text { I did the right thing when I decided to use this online vendor } \\
\text { that I have in mind. }\end{array}$ & 3.94 & 9.809 \\
\hline
\end{tabular}

Security (source: Guo, Ling \& Liu, 2012)

\begin{tabular}{llcc}
\hline & Questions & Mean & Std. deviation \\
\hline 1 & $\begin{array}{l}\text { I feel secure giving out credit card information at this } \\
\text { online vendor's website. }\end{array}$ & 3.78 & 0.923 \\
2 & This vendor's website has adequate security features. & 3.80 & 0.951 \\
3 & I feel I can trust this vendor's website. & 3.88 & 0.853 \\
4 & I feel safe in my transactions with this vendor's website. & 3.84 & 0.913 \\
5 & I believe this vendor's website provides accurate & 3.87 & 0.835 \\
& information to potential customers like me. & \\
\hline
\end{tabular}


WOM Communication (source: Palvia, 2009)

\begin{tabular}{llcc}
\hline & Questions & Mean & Std. deviation \\
\hline 1 & I tell my friend about this online vendor that I have in mind. & 3.94 & 0.832 \\
2 & $\begin{array}{l}\text { I want my friend to buy from this online vendor that I have } \\
\text { in mind. }\end{array}$ & 3.81 & 0.919 \\
\hline
\end{tabular}

Consumer Trust (source: Palvia, 2009)

\begin{tabular}{llcc}
\hline & Questions & Mean & Std. deviation \\
\hline 1 & I believe this vendor's website is trustworthy. & 3.99 & 0.782 \\
2 & I believe this vendor's website provides reliable information. & 4.01 & 0.799 \\
3 & $\begin{array}{l}\text { I believe this vendor's website keeps promises and } \\
\text { commitments. }\end{array}$ & 3.97 & 0.817 \\
4 & $\begin{array}{l}\text { I believe this vendor's behaviour keeps my best interests } \\
\text { in mind. }\end{array}$ & 3.93 & 0.788 \\
5 & I believe this vendor's behaviour meets my expectations. & 3.95 & 0.793 \\
\hline
\end{tabular}

